\title{
ACADEMIC PROCRASTINATION AND PERFORMANCE IN DISTANCE EDUCATION: \\ A CAUSAL-COMPARATIVE STUDY IN AN ONLINE LEARNING ENVIRONMENT
}

\author{
Dr. Hasan UCAR \\ ORCID: 0000-0001-9174-4299 \\ Open Education Faculty \\ Anadolu University \\ Eskisehir, TURKEY \\ Dr. Aras BOZKURT \\ ORCID: 0000-0002-4520-642X \\ Open Education Faculty \\ Anadolu University \\ Eskisehir, TURKEY \\ Dr. Olaf ZAWACKI-RICHTER \\ ORCID: 0000-0003-1482-8303 \\ University of Oldenburg \\ Oldenburg, GERMANY
}

Faculty of Education and Social Sciences

Received: 13/03/2020 Accepted: 04/06/2020

\begin{abstract}
Research indicates that academic procrastination is a common attitude among learners, and that it generally has a negative correlation with academic performance. The present quantitative causal-comparative study aims to determine the cause of differences, in terms of procrastination tendency, in academic performance among online learners. The study further investigates whether academic procrastination tendency significantly predicts the academic performance of online learners. The sample included a total of 333 online distance learners, from whom data were obtained through an online survey. Results showed that there was no statistically significant difference between male and female learners in terms of academic procrastination. Moreover, low procrastinators had better academic performance than that of high procrastinators, and learners' academic procrastination tendencies significantly predicted academic performance. These results demonstrate that academic procrastination tendency is an important indicator for predicting the academic achievements of online learners.
\end{abstract}

Keywords: Procrastination, academic performance, online learning, distance education, online learning environment.

\section{INTRODUCTION}

Online distance learning (ODL) has been gaining popularity, functioning now as a mainstream mode of education in current education systems on account of the limitations it eliminates for learners, instructors, and learning resources. However, despite the flexible learning opportunities and other advantages offered by ODL to learners, high dropout rates, low retention, academic performance problems, and academic procrastination issues continue to be very common in ODL (Cerezo, Esteban, Sánchez-Santillán, \& Nunez, 2017; Elvers, Polzella, \& Graetz, 2003; Hooshyar, 
Pedaste, \& Yang, 2020; Michinov, Brunot, Le Bohec, Juhel, \& Delaval, 2011; Wilkinson \& Sherman, 1991), due primarily to the fact that the educational delivery mode places almost all the learning and performance responsibility on learners. In ODL systems, learners are assumed to be self-regulated and capable of organizing and controlling their learning process, meaning that online learners should be motivated and self-regulated to fully benefit from the advantages offered by ODL. Therefore, in the context of ODL environments, online students need to be supported in terms of the self-regulation and motivation practices necessary for becoming independent learners - the truly autonomous student does not exist per se. As indicated from the theory and practice of distance education, student support services and scaffolding have always played a central role in open and distance education systems: "Distance learning can be very isolating, and inadequate attention to course design, student counselling and support can yield poor completion rates and the worst aspects of one-way knowledge transmission” (Brindley \& Paul, 1996, p. 43). The characteristics of distance learners are quite different from those seen on the traditional student profile (Stoter, Bullen, Zawacki-Richter, \& von Prummer, 2014; Thompson, 1996). The majority of the student population in ODL are working adults, whose lives require them to balance professional, private and social demands. By its very nature, ODL requires students to have more self-regulation skills. In this context, it can be said that online distance learners in unstructured learning environments are more prone to procrastination behavior (Deimann, \& Bastiaens, 2010; Klingsieck, Fries, Horz, \& Hofer, 2012; Ucar \& Bozkurt, 2018). For example, Tuckman (2005) found that lack of control and student self-control in distance learning environments led to excessive procrastination and poor performance, especially among procrastination prone learners. There are therefore many occasions that prevent students from learning or that cause them to postpone learning. Against this background, research on the topic of procrastination in distance learning is of particular importance. Thus, the purpose of this paper is to explore the procrastination behavior of nontraditional distance learning students in order to provide important information on the design of academic student support services at distance teaching institutions.

\section{LITERATURE REVIEW}

Procrastination can be considered a failure of self-regulation (Grund \& Fries, 2018; Grunschel, Patrzek, Klingsieck, \& Fries, 2018; Steel \& Klingsieck, 2016; Ucar \& Bozkurt, 2019; Uzun, Ferrari, \& LeBlanc, 2018). Steel (2007) defines procrastination as a "voluntary delay on intended course of action despite expecting to be worse off for the delay." (p. 66). Following Steel's (2007) definition, Klingsieck (2013) expanded the idea of procrastination and redefined it as "the voluntary delay of an intended and necessary and/or personally important activity, despite expecting potential negative consequences that outweigh the positive consequences of the delay." (p. 26). Steel and Klingsieck (2016) defined academic procrastination as "procrastination restricted to the tasks and activities related to and/or relevant for learning and studying." (p. 37).

A meta-analysis study conducted by Steel (2007) on procrastination revealed that $80 \%$ to $95 \%$ of the university students engaged in procrastination behavior. Moreover, $75 \%$ of these students viewed themselves as procrastinators, and most interesting of all, about $50 \%$ of these students said that they procrastinate all the time. From other studies conducted on this subject, including those by Fernie, Bharucha, Nikcevic, Marino, and Spada (2017), Sutcliffe, Sedley, Hunt, and Macaskill (2019), Ko and Chang (2019) and Steel (2007), it was recognized that academic procrastination is a common, albeit unfavorable behavior among learners, and that effort is needed to decrease the impact of this behavior.

Academic procrastination poses a major obstacle to the academic achievement of students (Asikhia, 2010; Steel \& Klingsieck, 2016). It is reported that there is a negative correlation between procrastination tendency and academic performance (Grunschel, Schwinger, Steinmayr, \& Fries, 2016; Hen \& Goroshit, 2018; Kim \& Seo, 2013, 2015). That is, high academic procrastination tendency is associated with low academic performance. According to Fernie et al. (2017), procrastination is a negative behavior, influencing students' 
academic performance negatively as well as lowering their effectiveness in their field of employment after the completion of their schooling. However, it is important to note that although Fernie et al. (2017) view procrastination as a negative behavior, most of academic procrastination was shown to be intentional and learners were very aware of that they engaged in this type of behavior. Alp and Sungur (2017) report that procrastination is substantially connected to academic achievement and therefore is a hot topic for educators. In line with these notions, academic procrastination is also significantly linked to goal accomplishment, that is, academic performance (Cormack, Eagle, \& Davies, 2020; Gustavson \& Miyake, 2017).

A majority of the research conducted on general procrastination and academic procrastination has been performed in face to face learning environments. As such, most of the research findings are related strictly to the face-to-face mode of learning. Only a limited amount of the research on academic procrastination has been conducted in distance education environments, and so the related literature on ODL has provided but a weak bulk of studies. For example, in an experimental study conducted by Elvers, Polzella, and Graetz (2003) comparing face-to-face and online learners in terms of their procrastination tendencies, the findings showed that online learners had low procrastination tendencies and better academic success than that of face-to-face learners. The researchers also highlighted that while procrastination tendency was an important indicator that could be used to predict online learners' performance, it was not a good indicator of performance for face-to-face learners. Another research study conducted by Cerezo et al. (2017) with 140 undergraduate students who were participating in an online course given through a learning management system (LMS) reported similar findings. In line with the above studies, Michinov et al. (2011) conducted research with 53 learners enrolled in an online learning program and reported that low procrastinators had better academic success than that of high procrastinators in online learning. However, the samples used in these three studies were relatively small. Thus, more research is needed to get a broader understanding of academic procrastination and its effects in online learning environments. Taking this into account, this study was conducted for the dual purpose of providing greater insight and expanding the body of research on procrastination in ODL.

\section{The Current Study}

As understood from the related literature, it is important to know the procrastination behaviors of the learners in ODL in order to take the necessary precautions in addressing academic procrastination tendency, as it is significantly related to course performance and accomplishment. Thus, this study aims to examine the possible differences in academic performance between online learners with high and low procrastination tendencies. In this context, the following research questions were developed:

1. Do male and female learners significantly differ in their level of procrastination tendencies?

Research hypothesis 1: Online male and female learners will score the same on academic procrastination.

2. Do procrastination tendency differences produce differences in the academic performance of online learners?

Research hypothesis 2: Online learners who scored lower on academic procrastination tendency will have better academic performance than that of those who scored higher on academic procrastination tendency.

3. Does academic procrastination tendency predict the academic performance of online learners?

Research hypothesis 3: The academic procrastination tendency of online learners will predict their academic performance.

\section{METHODOLOGY}

\section{Research Design}

This research aims to explore the effects of the academic procrastination tendencies of online learners in an online learning environment, and to determine the cause of the differences in academic performance that already exist among online learners. To these ends, the research applied a quantitative causal-comparative design (Fraenkel \& Wallen, 2012; Schenker \& Rumrill, 2004), in order to best determine "the cause and 
consequences of differences that already exist between or among groups of individuals" (Fraenkel \& Wallen, 2012, p. 363).

\section{Participants}

A total of 333 online undergraduate learners taking an online English course at a state university in Turkey participated in the study. While they took this course fully online, they were also attending face to face courses and the programs they enrolled were offering face to face courses. The participants ranged in age between 18 and 23 ( $\mathrm{M}_{\text {age }}=20.06$ years), and 205 were female $(61.6 \%)$ and 128 were male (38.4\%). All participants voluntarily agreed to participate in the study via an informed consent form that was embedded in the online survey.

\section{Procedure}

The data were collected through an online survey administered in the 2018-2019 spring term. The researchers sent a message about the survey to nearly 1,200 learners through the learner information system (LIS) and LMS. Of these learners, 680 viewed the survey, 444 started the survey, and 350 completed the survey, which means, approximately $51.5 \%$ of the learners who viewed the survey completed it. Of these completed surveys, a total of 12 were omitted because of incomplete items and repeated answers. As a result, the final data was collected from 333 survey respondents.

\section{Measures}

The online learners' academic procrastination tendencies were measured using the Turkish version of the Tuckman Procrastination Scale. This scale was translated and developed by Uzun Ozer, Sackes, and Tuckman (2013) from The Tuckman Procrastination Scale (Tuckman, 1991), a widely used, 14-item scale to measure the academic procrastination tendency of learners. The instrument is arranged as a four-point Likert-type scale (1-strongly disagree, 4-strongly agree) and has a single factor structure (Uzun Ozer, Sackes, \& Tuckman, 2013). The following is a sample item on the scale: "I needlessly delay finishing jobs, even when they're important." For the original scale administered to two different samples of undergraduate students, the Cronbach's alpha reliability coefficient was reported as 0.90 and 0.85 . In the current study, the Cronbach's alpha reliability coefficient of the scale was calculated as 0.65 , which is considered acceptable. Regarding the academic procrastination, a median split method was used to categorize the learners. With this method, the learners were labeled as low (22-34) and high (35-51) procrastinators, according to their total points on the procrastination scale. Grade point average was used to assess the academic performance of the learners. During the 14-week term, learners took three exams related to the course. The grade point average scores were calculated as follows: $10 \%$ of the score was based on the online quiz scores, $40 \%$ of the score was based on the mid-term exam, and $50 \%$ of the score was based on the final exam in the course.

\section{Data Analysis}

The data collected in this study were analyzed in terms of the procrastination tendency and academic performance. Independent samples t-test was employed to compare the means of the male and female learners' level of procrastination tendencies (research question 1) and to compare low and high procrastinators, in order to designate whether there was a statistical difference in their academic performance scores (research question 2). Finally, a simple linear regression model was used to predict the relationship between academic procrastination tendency and academic performance (research question 3).

\section{RESULTS}

The purpose of this study was to explore whether male and female learners in ODL would have different academic procrastination tendencies. In addition, the study examined whether different procrastination scores produced differences in academic performance. In this regard, the study explored whether academic 
procrastination tendency was able to predict the academic performance of online learners. The results related to the research questions are given below.

In order to answer research question 1, the independent samples t-test was used to compare the male and female learners' means on the academic procrastination scale. The results of the test showed that although the female learners' average mean score $(M=34.8, S D=4.1)$ was slightly higher than the male learners' average mean score $(\mathrm{M}=34.1, \mathrm{SD}=5.2)$, the difference was not statistically significant $\left(\mathrm{t}_{(331)}=1.18, p=0.23\right)$ in terms of academic procrastination. Thus, the result confirmed research hypothesis 1 .

To answer research question 2, the independent samples t-test was used to compare low and high academic procrastinators' means on academic performance scores. On average, low procrastinators had better academic performance $(\mathrm{M}=54.76, \mathrm{SD}=10.6, \mathrm{SE}=0.83)$ than that of high procrastinators $(\mathrm{M}=49.65, \mathrm{SD}=10.5$, $\mathrm{SE}=0.81)$. This difference was significant $\left(t_{(331)}=4.38, p<0.01\right)$, and it had close to a medium-sized effect $(d=0.48)$. Thus, the result confirmed research hypothesis 2 .

To answer research question 3, a simple linear regression model was used to predict the relationship between academic procrastination tendency and academic performance. Simple linear regression was used to assess whether learners' academic procrastination tendencies significantly predicted academic performance. The result of the regression suggested that learners' academic procrastination tendencies explained $0.2 \%$ of the variance, $(\mathrm{R} 2=0.023 ; \mathrm{F}(1,131)=7.808, \mathrm{p}<0.05)$ (Table 1 and 2$)$. In other words, the learners' academic procrastination tendencies significantly predicted academic performance $(B=-0.35, \mathrm{t}=-2.79, \mathrm{p}<0.05)$ (Table 3$)$, thus confirming hypothesis 3.

Table 1. Summary of the regression model

\begin{tabular}{|c|c|c|c|c|c|c|c|}
\hline \multirow{2}{*}{ Model } & \multirow{2}{*}{$\mathrm{R}$} & \multirow{2}{*}{$\mathrm{R}^{2}$} & \multirow{2}{*}{ Adj. $R^{2}$} & \multirow{2}{*}{ SEM } & \multicolumn{3}{|c|}{ Change Statistics } \\
\hline & & & & & $\mathrm{R}^{2}$ & $F$ & $P$ \\
\hline 1 & $0.152^{\mathrm{a}}$ & 0.023 & 0.020 & 10.78 & 0.023 & 7.80 & 0.006 \\
\hline
\end{tabular}

a. Predictors: (Constant), academic procrastination tendency

Table 2. Summary of Analysis of Variance results

\begin{tabular}{|c|c|c|c|c|c|c|}
\hline & Model & SS & $d f$ & MS & $\mathrm{F}$ & $P$ \\
\hline \multirow[t]{3}{*}{1} & Regression & 908.741 & 1 & 908.74 & 7.80 & $0.006^{b}$ \\
\hline & Residual & 38523.13 & 331 & 116.38 & & \\
\hline & Total & 39431.88 & 332 & & & \\
\hline
\end{tabular}

a. Dependent Variable: academic performance, b. Predictors: (Constant), academic procrastination tendency

Table 3. Coefficients

\begin{tabular}{|c|c|c|c|c|c|c|}
\hline \multirow[t]{2}{*}{ Model } & \multicolumn{6}{|c|}{ Unstandardized } \\
\hline & B & & & $\beta$ & $\mathrm{t}$ & $P$ \\
\hline \multirow[t]{2}{*}{1} & (Constant) & 64.559 & 4.478 & & 14.418 & 0.000 \\
\hline & procrastination & -.359 & 0.128 & -.152 & -2.794 & 0.006 \\
\hline
\end{tabular}

a. Dependent Variable: academic performance 


\section{DISCUSSION}

The present study aimed to examine possible differences related to academic performance and gender between online learners with high and low procrastination tendency. The research findings indicated that there was no significant difference between male and female online learners in terms of academic procrastination, which means that academic procrastination is a gender-free issue. This result is consistent with previous work conducted on this subject by Hess, Sherman, and Goodman (2000), Uzun Ozer and Ferrari (2011), and Watson (2001), all of whom investigated gender role differences in academic procrastination in faceto-face educational settings. However, in a different study by Steel (2007), contradictory findings were reported. Accordingly, in his meta-analytic study on research investigating possible causes and effects of procrastination, it was reported that male learners procrastinate slightly more than female learners.

Previous studies researching procrastination among face to face undergraduate students reached similar findings, showing that male learners' procrastination tendency is significantly higher than that of females (Fernie et al., 2017; Uzun Ozer, Demir, \& Ferrari, 2009; Uzun Ozer, 2014; Yockey, 2016). This finding is also supported by Steel and Ferrari's (2013) study which surveyed 16413 adults and found that procrastination was strongly associated with gender. Another study conducted by Baltaci (2017) with primary school teachers also reported the same findings. The different research findings suggest that procrastination, in terms of gender, can be affected by a wide array of variables, including subject area, delivery modes of educational content, digital literacies of distance education learners, and socio-economic status of learners (e.g., employment status, social roles). In the context of distance education, most of the open universities deliver educational content to a massive number of students. For instance, at Anadolu University, a giga university with 3 million enrolled learners, the age range of students is 18 to 68 and they come from diverse socioeconomic backgrounds (Bozkurt, 2019). Considering that the age span and socio-economic status of the learners in the present study were narrower in range (e.g., from 18 to 23, undergraduate young learners), a different age span may lead to different research findings. This finding further implies that future research should consider different demographics to better examine and gain more insight into the academic procrastination phenomenon.

Another result from the present study, albeit it represented a medium-sized effect, was that low procrastinators had better academic performance. This finding is in line with previous studies conducted in online learning environments showing that low procrastinators have better academic success than that of high procrastinators (Cerezo et al., 2017; Michinov et al., 2011). Grunschel et al. (2016) conducted two studies with campus-based undergraduate students and reported a similar finding. Consistent with these findings, Kim and Seo (2015), carried out a meta-analysis study and found there to be a negative correlation between procrastination and academic performance. Thus, in general, learners with low achievement have high procrastination tendencies. The present research provides additional data on the relationship between academic performance and procrastination and contributes to the limited research corpus on this issue in online distance learning. However, it should be further taken into account that learners' self-regulation skills matter in distance education; therefore, additional studies could examine the relationship between selfregulation and academic procrastination.

Regarding the third research question, the present study found that online learners' academic procrastination tendencies significantly predicted academic performance. This finding is consistent with the findings reported in the studies by Elvers, Polzella, and Graetz (2003) and Hooshyar, Pedaste, and Yang's (2020), which revealed that learners' performance can be predicted successfully through learners' procrastination tendencies in online distance learning. In addition, Elvers, Polzella, and Graetz (2003) indicated that procrastination was a good predictor of performance "for the online students", but not a good predictor of performance "for the lecture students" (p.162). However, in the study by Cormack, Eagle, and Davies (2020), although a significant negative relationship was found between these two variables, the researchers stated that procrastination was not a strong factor associated with academic performance within the context of the study. Many of the studies found in the related literature (e.g., Grund \& Fries, 2018; Gustavson \& Miyake, 2017; Kim \& Seo, 2013, 2015; Wäschle, Allgaier, Lachner, Fink, \& Nuckles, 2014) also confirm the finding of the current study. In contrast, Seo (2011) and Schraw, Wadkins, and Olafson (2007) report contradictory results, finding no significant relationship between learners' procrastination tendencies and their course achievement. Although new studies have revealed there to be a significant negative relationship between procrastination tendency and academic achievement, further research is still needed in the field of online distance education. 


\section{Limitations and Future Research}

Although this study collected substantial findings on academic procrastination, there are some limitations that must be acknowledged. The participants of the study were undergraduates who were taking courses online as well as face-to-face courses. Therefore, these participants cannot be considered as fully online distance learners. To this end, future studies should be conducted with fully online distance learners to compare the findings presented in the current study. Another limitation was the research design of the study. Since independent variables are not manipulated in causal-comparative research designs, internal validity cannot be assured. On this account, the researchers are not sure whether changes in the dependent variables were caused by the independent variables. Future studies should be carried out using experimental research designs to eliminate this limitation. The sample size can also be partially counted as a limitation. Future studies should consider larger samples in the online distance education context to compare the findings presented in this study. In addition, qualitative studies that include physiological dimensions are needed to understand the root causes of academic procrastination in online learning environments. Additionally, future research examining variables like marital status, employment, age-range, or study conditions of online distance learners will further explain procrastination issue in ODL settings.

\section{CONCLUSION}

This study focused on the academic procrastination tendency and performance of online learners. The results of the study showed that low procrastinators had better academic performance than high procrastinators in the online learning environment. Moreover, it was found that online distance learners' academic procrastination tendencies significantly predicted their academic performance. In addition, no significant difference was found between male and female online learners in terms of academic procrastination. In brief, similar to the results reported in previous studies, the findings from this study indicate that academic procrastination has a notable effect on academic performance. To better understand online learners' academic procrastination tendencies, instructional designers or instructors would be able to design motivational strategies or activities that reduce academic procrastination for online distance learners. Early warning systems could be designed to detect at risk students based on their procrastination behavior patterns. Besides, future studies focusing on the internal motives (e.g., motivation, anxiety, etc.), skills and competencies (e.g., digital literacy) can contribute to the related literature to better understand the phenomenon.

\section{BIODATA and CONTACT ADDRESSES of AUTHORS}

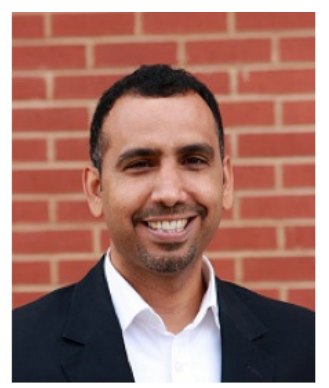

Dr. Hasan UCAR is an Associate Professor of Open and Distance Education at Open Education Faculty, Anadolu University. Dr. Ucar received his Ph.D. (2016) and master's degree (2012) in Distance Education from Anadolu University, Turkey. Hasan's current research agenda is the motivational design of instruction in online learning environments. Additional areas of research include distance learning and teaching, online learning, instructional design/technology, teaching and learning in online technologies, motivation and engagement of online learners, and online academic procrastination.

\section{Hasan UCAR}

Department of Distance Education, Open Education Faculty

Address: Anadolu University, Open Education Faculty, 26470, Eskisehir, Turkey

Phone: +90 2223350580/3925

E-mail: hasanucar@anadolu.edu.tr 


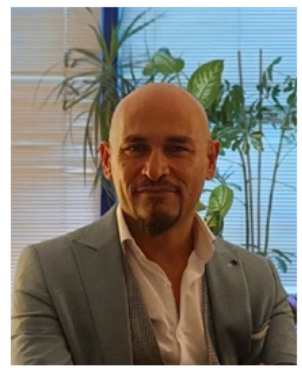

Dr. Aras BOZKURT is a researcher and faculty member in the Department of Distance Education, Open Education Faculty at Anadolu University, Turkey. $\mathrm{He}$ holds MA and PhD degrees in distance education. Dr. Bozkurt conducts empirical studies on distance education, open and distance learning, and online learning, to which he applies various critical theories, such as connectivism, rhizomatic learning, and heutagogy. He is also interested in emerging research paradigms, including social network analysis, sentiment analysis, and data mining.

\section{Aras BOZKURT}

Department of Distance Education, Open Education Faculty

Address: Anadolu University, Open Education Faculty, 26470, Eskisehir, Turkey

Phone: +90 2223350580

E-mail: arasbozkurt@gmail.com

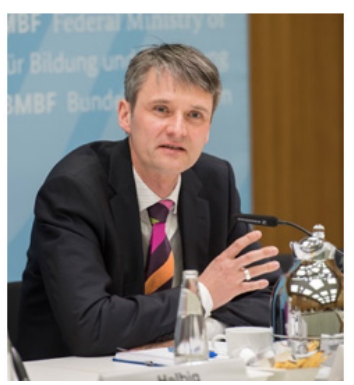

Dr. Olaf ZAWACKI-RICHTER is a Professor of Educational Technology at the University of Oldenburg in Germany. Olaf is the Dean of the Faculty of Education and Social Sciences, and he is directing the Center for Open Education Research (COER), and the Center for Lifelong Learning (C3L). He is the author of over 160 publications in peer-reviewed journals and books in the field of open, distance, and digital education. Dr. Zawacki-Richter is Associate Editor of the SSCI journal "Distance Education" and a member of the editorial board of the "International Review of Research in Open and Distance Learning" (IRRODL), "Open Learning" and the "Journal for Higher Education Development". Olaf has served as invited keynote speaker, chair and reviewer at many international conferences.

\section{Olaf ZAWACKI-RICHTER}

Faculty of Education and Social Sciences

Address: University of Oldenburg, 26111 Oldenburg, Germany

Phone: +49 441798-2765

E-mail: olaf.zawacki.richter@uni-oldenburg.de

\section{REFERENCES}

Alp, A., \& Sungur, S. (2017). Investigating relationships between undergraduate students' flow experience, academic procrastination behavior, and calculus course achievement. Eurasian Journal of Educational Research, 17(72), 1-22. https://doi.org/10.14689/ejer.2017.72.1

Asikhia, O. A. (2010). Academic procrastination in mathematics: causes, dangers and implications of counselling for effective learning. International Education Studies, 3(3). https://doi.org/10.5539/ ies.v3n3p205

Baltaci, A. (2017). Sinif oğretmenlerinin erteleme davranişi eğilimleri ve kişilik ozellikleri arasindaki ilişkiler. OPUS Uluslararasi Toplum Araştirmalari Dergisi, 7(12), 54-81.

Bozkurt, A. (2019). The Historical Development and Adaptation of Open Universities in Turkish Context: Case of Anadolu University as a Giga University. The International Review of Research in Open and Distributed Learning, 20(4). https://doi.org/10.19173/irrodl.v20i4.4086

Brindley, J. E., \& Paul, R. (1996). Lessons from distance education for the university of the future. In R. Mills \& A. Tait (Eds.), Supporting the learner in open and distance learning (pp. 43-55). Pitman Publishing.

Cerezo, R., Esteban, M., Sánchez-Santillán, M., \& Nunez, J. C. (2017). Procrastinating behavior in computer-based learning environments to predict performance: A case study in Moodle. Frontiers in psychology, 8, 1403. https://doi.org/10.3389/fpsyg.2017.01403 
Cormack, S. H., Eagle, L. A., \& Davies, M. S. (2020). A large-scale test of the relationship between procrastination and performance using learning analytics. Assessment \& Evaluation in Higher Education, 1-14. https://doi.org/10.1080/02602938.2019.1705244

Deimann, M., \& Bastiaens, T. (2010). The role of volition in distance education: An exploration of its capacities. The International Review of Research in Open and Distributed Learning, 11(1), 1-16. https://doi.org/10.19173/irrodl.v11i1.778

Elvers, G. C., Polzella, D. J., \& Graetz, K. (2003). Procrastination in online courses: Performance and attitudinal differences. Teaching of Psychology, 30(2), 159-162. https://doi.org/10.1207/ s15328023top3002_13

Fernie, B. A., Bharucha, Z., Nikcevic, A. V., Marino, C., \& Spada, M. M. (2017). A Metacognitive model of procrastination. Journal of Affective Disorders, 210, 196-203. https://doi.org/10.1016/j. jad.2016.12.042

Fraenkel, J. R. \& Wallen, N. E. (2012). How to design and evaluate research in education (7th ed.). New York: McGraw-Hill.

Grund, A., \& Fries, S. (2018). Understanding procrastination: A motivational approach. Personality and Individual Differences, 121, 120-130. https://doi.org/10.1016/j.paid.2017.09.035

Grunschel, C., Patrzek, J., Klingsieck, K. B., \& Fries, S. (2018). "I'll stop procrastinating now!" Fostering specific processes of self-regulated learning to reduce academic procrastination. Journal of Prevention \& Intervention in the Community, 46(2), 143-157. https://doi.org/10.1080/1085235 2.2016.1198166

Grunschel, C., Schwinger, M., Steinmayr, R., \& Fries, S. (2016). Effects of using motivational regulation strategies on students' academic procrastination, academic performance, and well-being. Learning and Individual Differences, 49, 162-170. https://doi.org/10.1016/j.lindif.2016.06.008

Gustavson, D. E., \& Miyake, A. (2017). Academic procrastination and goal accomplishment: A combined experimental and individual differences investigation. Learning and Individual Differences, 54, 160-172. https://doi.org/10.1016/j.lindif.2017.01.010

Hen, M., \& Goroshit, M. (2018). The effects of decisional and academic procrastination on students' feelings toward academic procrastination. Current Psychology. 1-8. https://doi.org/10.1007/s12144-0179777-3

Hess, B., Sherman, M. F., \& Goodman, M. (2000). Eveningness predicts academic procrastination: The mediating role of neuroticism. Journal of Social Behavior and Personality, 15(5), 61-74.

Hooshyar, D., Pedaste, M., \& Yang, Y. (2020). Mining Educational Data to Predict Students' Performance through Procrastination Behavior. Entropy, 22(1), 12. https://doi.org/10.3390/e22010012

Kim, E., \& Seo, E. H. (2013). The Relationship of Flow and Self-Regulated Learning to Active Procrastination. Social Behavior and Personality: An International Journal, 41(7), 1099-1113. https://doi.org/10.2224/sbp.2013.41.7.1099

Kim, K. R., \& Seo, E. H. (2015). The relationship between procrastination and academic performance: A meta-analysis. Personality and Individual Differences, 82, 26-33. https://doi.org/10.1016/j. paid.2015.02.038

Klingsieck, K. B. (2013). Procrastination: When good things don't come to those who wait. European Psychologist, 18(1), 24-34. https://doi.org/10.1027/1016-9040/a000138

Klingsieck, K. B., Fries, S., Horz, C., \& Hofer, M. (2012). Procrastination in a distance university setting. Distance Education, 33(3), 295-310. https://doi.org/10.1080/01587919.2012.723165

Ko, C. Y. A., \& Chang, Y. (2019). Investigating the relationships among resilience, social anxiety, and procrastination in a sample of college students. Psychological Reports, 122(1), 231-245. https://doi. org/10.1177/0033294118755111 
Michinov, N., Brunot, S., Le Bohec, O., Juhel, J., \& Delaval, M. (2011). Procrastination, participation, and performance in online learning environments. Computers \& Education, 56(1), 243-252. https:// doi.org/10.1016/j.compedu.2010.07.025

Schenker, J. D., \& Rumrill Jr, P. D. (2004). Causal-comparative research designs. Journal of vocational rehabilitation, 21(3), 117-121. https://content.iospress.com/articles/journal-of-vocationalrehabilitation/jvr00260

Schraw, G., Wadkins, T., \& Olafson, L. (2007). Doing the things we do: A grounded theory of academic procrastination. Journal of Educational Psychology, 99(1), 12-25. https://doi.org/10.1037/00220663.99.1.12

Seo, E. H. (2011). The relationships among procrastination, flow, and academic achievement. Social Behavior and Personality: an international journal, 39(2), 209-217. https://doi.org/10.2224/ sbp.2011.39.2.209

Steel, P. (2007). The nature of procrastination: A meta-analytic and theoretical review of quintessential self-regulatory failure. Psychological Bulletin, 133(1), 65-94. https://doi.org/10.1037/00332909.133.1.65

Steel, P., \& Ferrari, J. (2013). Sex, education and procrastination: An epidemiological study of procrastinators' characteristics from a global sample. European Journal of Personality, 27(1), 51-58. https://doi. org/10.1002/per.1851

Steel, P., \& Klingsieck, K. B. (2016). Academic Procrastination: Psychological Antecedents Revisited. Australian Psychologist, 51(1), 36-46. https://doi.org/10.1111/ap.12173

Stoter, J., Bullen, M., Zawacki-Richter, O., \& von Prummer, C. (2014). From the back door into the mainstream - the characteristics of lifelong learners. In O. Zawacki-Richter \& T. Anderson (Eds.), Online distance education -Towards a research agenda (pp. 421-457). Athabasca University Press.

Sutcliffe, K. R., Sedley, B., Hunt, M. J., \& Macaskill, A. C. (2019). Relationships among academic procrastination, psychological flexibility, and delay discounting. Behavior Analysis: Research and Practice, 19(4), 315. http://dx.doi.org/10.1037/bar0000145

Thompson, M. M. (1998). Distance learners in higher education. In C. C. Gibson (Ed.), Distance learners in higher education (pp. 9-24). Atwood Publishing.

Tuckman, B. W. (1991). The development and concurrent validity of the Procrastination Scale. Educational and Psychological Measurement, 51, 473 - 480. https://doi.org/10.1177/0013164491512022

Ucar, H., \& Bozkurt, A. (2019). Using motivation, volition, and performance model to overcome online procrastination. In T. Erdoğan, \& S. Ozer. (Eds), Current Academic Studies in Social Sciences (pp. 105-112). Cetinje-Montenegro; IVPE.

Ucar, H., \& Bozkurt, A. (2018). Uzaktan eğitimde akademik erteleme davranişinin ustesinden gelmek icin motivasyon, eylem ve başari modelinin kullanimi. 5th International Symposium On Multidisciplinary Studies (ISMS) (p. 1210). 16-17 December, Ankara, Turkey.

Uzun Ozer, B. (2014). Psychometric properties of adult inventory of procrastination in a Turkish sample. Journal of Adult Development, 21(1), 43-47. https://doi.org/10.1007/s10804-013-9177-3

Uzun Ozer, B., \& Ferrari, J. R. (2011). Gender orientation and academic procrastination: Exploring Turkish high school students. Individual Differences Research, 9(1), 33-40.

Uzun Ozer, B., Demir, A., \& Ferrari, J. R. (2009). Exploring academic procrastination among Turkish students: Possible gender differences in prevalence and reasons. The Journal of social psychology, 149(2), 241-257. https://doi.org/10.3200/socp.149.2.241-257

Uzun Ozer, B., Sackes, M., \& Tuckman, B. W. (2013). Psychometric properties of the Tuckman Procrastination Scale in a Turkish sample. Psychological Reports, 113(3), 874-884. https://doi. org/10.2466/03.20.pr0.113x28z7 
Uzun, B., Ferrari, J. R., \& LeBlanc, S. (2018). Put Aside Procrastination: Positive Emotional Outcomes from Self-Forgiveness for Delays. North American Journal of Psychology, 20(1). 171-186.

Wäschle, K., Allgaier, A., Lachner, A., Fink, S., \& Nuckles, M. (2014). Procrastination and self-efficacy: Tracing vicious and virtuous circles in self-regulated learning. Learning and Instruction, 29, 103114. https://doi.org/10.1016/j.learninstruc.2013.09.005

Watson, D. C. (2001). Procrastination and the five-factor model: A facet level analysis. Personality and individual differences, 30(1), 149-158. https://doi.org/10.1016/s0191-8869(00)00019-2

Wilkinson, T., \& Sherman, T. (1991). Procrastination in distance education: a review of what we know and need to learn. Open Learning: The Journal of Open, Distance and e-Learning, 6(3), 32-38. https:// doi.org/10.1080/0268051910060305

Yockey, R. D. (2016). Validation of the short form of the academic procrastination scale. Psychological Reports, 118(1), 171-179. https://doi.org/10.1177/0033294115626825 